\title{
A NEW SCORING SYSTEM FOR COVID-19 IN PATIENTS ON HEMODIALYSIS: MODIFIED EARLY WARNING SCORE
}

\section{AUTHORS}

CORRESPONDENT

Professor Radojica Stolić

Faculty of Medical Sciences

Kragujevac

radojica.stolic@med.pr.ac.rs

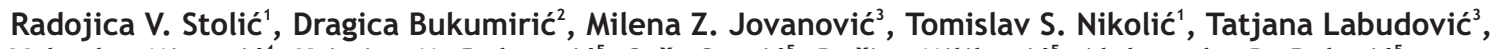
Vekoslav Mitrović ${ }^{4}$, Kristina M. Bulatović ${ }^{5}$, Saša Sovtić ${ }^{5}$, Dušica Miljković ${ }^{5}$, Aleksandra D. Balović ${ }^{5}$, Roksanda N. Krivcević ${ }^{5}$, Sanja M. Jovanović ${ }^{5}$

${ }^{1}$ University of Kragujevac, Serbia, Faculty of Medical Sciences, Department of Internal Medicine, Serbia

${ }^{2}$ Department of Planning, Analysing and Statistics, Primary Health Care Center, Pancevo, Serbia

${ }^{3}$ Center for Nephrology and Dialysis, Clinical Center Kragujevac, Serbia

${ }^{4}$ University of East Sarajevo, Faculty of Medicine Foca, Republika Srpska, Bosnia and Herzegovina

${ }^{5}$ University of Pristina/K. Mitrovica, Serbia, Medical Faculty Pristina/K. Mitrovica, Serbia

\section{SUMMARY}

Introduction. At the very beginning of the Corona virus epidemic there was not enough data on whether hemodialysis patients have a higher risk for Corona virus infection and which factors may affect the severity of clinical picture.

Objective. The aim of the study was to determine the significance of the Modified Early Warning Assessment (MEWS) score for the assessment of coronavirus disease exacerbation.

Methods. The research was conducted in COVID dialysis, as a retrospective, descriptive-analytical study, at the University Clinical Center Kragujevac, Serbia, which was organized ad-hoc for treatment of SARS-Cov-2 infection positive patients, which are transfered from Center for Hemodialysis „Ćuprija“. They were evaluated routine laboratory findings, demographic and gender structure, arterial blood pressure, presence of comorbidities and residual diuresis, duration of dialysis, radiological evaluation of lungs, determination of MEWS score were the parameters that were monitored. The results were monitored on admission and and in the end of treatment.

Results. A statistically significant difference was registered in serum lactate dehydrogenase concentration (486 \pm 107.62 vs. $423.7 \pm 92.4 \mathrm{U} / \mathrm{L}) ; \mathrm{p}=0.022$ and absolute monocyte count $(0.46 \pm 0.15$ vs. $0.67 \pm 0.34 \times 103 ; p=0.008)$. The significant increase in MEWS score was also found ( $b=0.017 ; p=0.030)$. There was a positive correlation between increase of MEWS score and age $(b=0.027 ; p=0.002)$ and arterial hypertension as a concomitant comorbidity $(b=0.700 ; p=0.033)$.

Conclusion. In the observed period, there was a significant increase in the degree of MEWS score of dialysis patients who had SARS-Cov-2 infection.

Keywords: SARS-Cov-2 infection, Hemodialysis, MEWS score, Predictor, Worsening

\section{SRPSKI}

\section{NOVI SISTEM BODOVANJA ZA COVID-19 PACIJENATA NA HEMODIJALIZI: MODIFIKOVANI SKOR RANOG UPOZORENJA}

Radojica V. Stolić1, Dragica Bukumirić ${ }^{2}$, Milena Z. Jovanović ${ }^{3}$, Tomislav S. Nikolić ${ }^{1}$, Tatjana Labudović ${ }^{3}$, Vekoslav Mitrović ${ }^{4}$, Kristina M. Bulatović ${ }^{5}$, Saša Sovtić ${ }^{5}$, Dušica Miljkovićs, Aleksandra D. Balović ${ }^{5}$, Roksanda N. Krivcevićc ${ }^{5}$, Sanja M. Jovanović ${ }^{5}$

${ }^{1}$ Univerzitet u Kragujevcu, Srbija, Fakultet medicinskihg nauka, Katedra Interne medicine, Srbija

${ }^{2}$ Odeljenje za planiranje, analizu i statistiku, Dom primarne zdravstvene zaštite, Pančevo, Srbija

${ }^{3}$ Centar za nefrologiju i dijalizu, Univerzitetski klinički centar Kragujevac, Srbija

${ }^{4}$ Univerzitet u Istočnom Sarajevu, Medicinski fakultet Foča, Republika Srpska, Bosna i Hercegovina

${ }^{5}$ Univerzitet u Prištini/K. Mitrovica, Srbija, Medicinski fakkultet Priština/K. Mitrovica 


\section{SAŽETAK}

Uvod: Na samom početku epidemije korona virusa nije bilo dovoljno podataka o tome da li pacijenti na hemodijalizi imaju veći rizik od infekcije korona virusom i koji faktori mogu uticati na ozbiljnost kliničke slike.

Cilj: Cilj studije bio je da se utvrdi značaj Modifikovane procene ranog upozorenja (MEWS) za procenu pogoršanja koronavirusne bolesti.

Metode: Istraživanje je sprovedeno kod bolesnika kojima je evidentirana SARS-Cov -2 infekcija, koji su lečeni u COVID dijalizi, kao retrospektivna, opisno-analitička studija, u Univerzitetskom kliničkom centru Kragujevac, Srbija, koja je organizovana ad-hoc za lečenje pacijenata iz Centra za hemodijalizu „Ćuprija“. Analizirani su rutinski laboratorijski nalazi, demografska i polna struktura, arterijski krvni pritisak, prisustvo komorbiditeta i rezidualne diureze, dužinu trajanje dijalize, radiološka procena pluća a određivan je i MEWS skor za sve bolesnike. Rezultati su praćeni pri prijemu i na kraju lečenja.

Rezultati: Statistički značajna razlika registrovana je u koncentraciji laktat dehidrogenaze u serumu $(486 \pm 107,62$ vs. 423,7 \pm $92,4 \mathrm{U} / \mathrm{L}) ; p=0,022$ i apsolutnom broju monocita $(0,46 \pm 0,15$ vs. 0,67 $\pm 0,34 \times 103 ; p=0,008)$. Utvrđen je značajno povećan MEWS skor $(b=0,017 ; p=0,030)$. Postojala je pozitivna korelacija između povećanja MEWS skora i starosti $(b=0,027 ; p=$ $0,002)$, kao $i$ arterijske hipertenzije $(b=0,700 ; p=0,033)$.

Zaključak: U posmatranom periodu došlo je do značajnog povećanja MEWS skora kod pacijenata na hemodijalizi koji su imali SARS-Cov - 2 infekciju.

Ključne reči: infekcija SARS-Cov-2, hemodijaliza, MEWS skor, prediktor, pogoršanje

\section{INTRODUCTION}

New coronavirus disease (COVID-19) is a newly discovered infectious disease caused by severe acute respiratory syndrome (SARS) - coronavirus (CoV) - 2 virus, which often manifests as acute respiratory disease with interstitial and alveolar pneumonia, and may affect other organs. COVID-19 is transmitted from person to person by droplets, faeces or direct contact and has an incubation period estimated at 1 to 14 days (usually 3 to 7 days). Diagnosis is mainly based on epidemiological parameters, clinical manifestations, laboratory and radiological examinations [1].

Hemodialysis patients represent a special group of patients with certain characteristics that can make them susceptible to infections or severe diseases. They may be at increased risk of COVID-19 infection due to many comorbid conditions. Due to association of uremic status with severe impairment of lymphocyte and granulocyte function, an abnormal immune system may alter the response to SARSCoV infection [2].

Mortality is estimated at $1.4-3.6 \%$, but may be higher or lower as the number of cases increases. Age and higher comorbidities are risk factors for respiratory distress syndrome and death. The challenge of COVID-19 is very different: as the disease spreads through the community, many dialysis patients in the same geographic area are likely to become infected and require continuous dialysis treatment. Thrice a week dialysis poses a risk of spreading the infection among patients and staff [3].

Vital signs (respiratory rate, oxygen saturation, blood pressure, pulse and temperature) are the simplest, cheapest and probably the most important data on hospitalized patients. However, despite their introduction into clinical practice more than a century ago, there are surprisingly few attempts to quantify their clinical significance. The importance of monitoring vital signs in clinical practice is undisputed, but it is still unclear how best to monitor and interpret them and how often they should be measured [4].

In this work, we want to transfer our own experiences from the Center for Nephrology and Dialysis of the University Clinical Center Kragujevac, Serbia, in organizing the nephrology service in a state of declared pandemic COVID-19 infection, and, above all, to determine the impact of the Modified Early Warning Score (MEWS) to the worsening of the clinical picture of COVID-19 positive patients, who are being treated with chronic hemodialysis.olesti renalnih arterija (RA) je neo-phodnpobubrega.

\section{METHODOLOGY}

In the University Clinical Center Kragujevac, Serbia, due to the epidemic of COVID-19 infection, a COVID-19 system was established, which included the organization of CORONA centers.

The organization of the nephrology service in CORONA dialysis was technically highly demanding due to the necessity of complete equipping the space in which, COVIDpositive patients, from the neighboring Dialysis Center (Ćuprija-Serbia) will be dialyzed in a very short time. The inclusion criteria for patient enrollment in this study is patients who had were positive on SARS-Cov-2. To register infections was used a polymerase chain reaction (PCR) test which one detects the presence of a virus. The treatment of patients in their home center was disabled due to the large number of infected medical and non-medical staff. In the organizational and professional sense, according to all the rules of the epidemiological profession, not only the space, but also all logistics, the installation of four hemodialysis machines and two mobile reverse osmosis devices were arranged. Within the CORONA dialysis center, three nephrologists and one secondary doctor were hired, as well as six nurses and technicians. This was a precondition for the application of all epidemiological measures for the isolation of patients and measures for the protection of medical and non-medical workers, enabling these patients to receive regular treatment with chronic dialysis.

During a epidemic of COVID-19 infection, in the process treating patients on hemodialysis, the role of the nurse and technician is the most important. Their job it is not just the implementation of the dialysis procedure, but also to inform doctors about any change in the clinical condition. Also, for the purposes of this study, they collected parameters for the verification a MEWS, at the beginning and end of treatment.

Our research was conducted in the COVID dialysis center. Demographic and gender structure, dialysis length, 
residual urine, radiological diagnosis of the lungs at the beginning and end of treatment, comorbidities were determined and routine laboratory analyzes were performed. A MEWS was calculated daily, for each patient, and used for early orientation of severity of the patient's general condition. The MEWS is based on several physiological parameters: age, number of respirations, oxygen saturation, need for oxygen therapy, values of systolic tension, body temperature, heart rate and state of consciousness. Based on the MEWS, a meaning was formed for each group: 0 - 1: Suggests that there is a need for a new control in the next 12 to 24 hours and that the patient can still be monitored by a nurse. 2-4: It is suggested that the patient remain under the supervision of a specialized nurse on the ward and that the next check-up should be in the next 2 to 8 hours, depending on the patient's status. 5 and more: The probability of the patient being transferred to an intensive care unit is increased, due to the need for specialized care in accordance with medical needs. High-risk patients have a need for more frequent monitoring and control and require treatment in intensive care units, they have an extremely high risk of failure of multiple systems and organs and enter or have entered an irreversible state. According to the sum of given points, for each parameter, the degree of risk for worsening of the clinical course of the disease was determined and measures of early intervention for their effective treatment were taken. The model, in fact, identifies the likelihood that the patient's clinical condition will worsen, which is defined as lethal outcome exit or admission to the intensive care unit [5].

Due to the current epidemic situation, the decision of the Ethics Committee in our institution for conducting this study was not requested.

\section{STATISTICAL ANALYSIS}

Depending on the type of variables and the normality of the distribution, the data description is shown as $\mathrm{n}(\%)$, as \pm sd or median (min-max). The t-test for two dependent samples and the Wilcoxon test were applied for testing statistical hyoptheses. The change in MEWS degree over time was analyzed by the Mixed Effect Regression model. Data analysis was performed in statistical software tools: SPSS 22.0 (SPSS Inc, Chicago, IL, U.S.A.) and R-3.5.0 software (The R Foundation for Statistical Computing, Vienna, Austria).

\section{RESULTS}

Among twelve patients treated in the CORONA 4 dialysis center, there were $8(66.7 \%)$ women and $4(33.3 \%)$ men, with a mean age of $62.5 \pm 13$ years, with the average period spent on dialysis $18 \pm 64.9$ month. The most common comorbidity was arterial hypertension, in $9(75 \%)$ patients, $8(67 \%)$ patients had preserved diuresis, 3 (25\%) patients had radiological signs of pneumonia, (Table 1 ).
Table 1. Demographic, clinical and radiological characteristics of patients treated in the COVID dialysis center

\begin{tabular}{lc}
\hline Variables & Patients $(\mathrm{n}=12)$ \\
\hline Age in years, mean \pm sd & $62.5 \pm 13$ \\
Gender $(\mathrm{n} / \%)$ & \\
Male & $8(67)$ \\
Female & $4(33)$ \\
Comorbidity ( $\mathrm{n} / \%)$ & \\
$\quad$ Hypertension & $9(75)$ \\
$\quad$ Diabetes mellitus & $5(42)$ \\
$\quad$ Other & $3(25)$ \\
Admission chest ※ay (n/\%) & \\
Pneumonia & $3(25)$ \\
Negative finding & $9(75)$ \\
Diuresis ( $\mathrm{n} / \%)$ & \\
Yes & $8(67)$ \\
No & $4(33)$ \\
Dialysis length irmonths, mean $\pm \mathrm{sd}$ & $64.9 \pm 18$ \\
\hline
\end{tabular}

Average values of biochemical parameters at admission and discharge are given in Table 2.

Table 2. Values of important laboratory parameters for the treatment of COVID-positive patients

\begin{tabular}{|c|c|c|}
\hline Laboratory variables & Patients $(n=12)$ & $P$ \\
\hline \multicolumn{3}{|l|}{ Leukocytes $\times 10^{2} ;($ mean $\pm \mathrm{sd})$} \\
\hline Baseline & $6.63 \pm 2.59$ & 0.197 \\
\hline At the end of teatment & $7.62 \pm 3.31$ & \\
\hline \multicolumn{3}{|l|}{ Lymphocites $\times 10^{2} ;($ mean $\pm s d)$} \\
\hline Baseline & $1.1 \pm 0.5$ & 0.217 \\
\hline At the end of treatment & $1.27 \pm 0.46$ & \\
\hline \multicolumn{3}{|l|}{ Monocytes x $10,($ mean $\pm s d)$} \\
\hline Baseline & $0.46 \pm 0.15$ & $0.008^{*}$ \\
\hline At the end of treatment & $0.67 \pm 0.34$ & \\
\hline \multicolumn{3}{|l|}{ Erythrocytes $\times 10^{2} / L ;($ mean $\pm s d)$} \\
\hline Baseline & $3.2 \pm 0.76$ & 0.432 \\
\hline At the end of treatment & $3.09 \pm 0.53$ & \\
\hline \multicolumn{3}{|l|}{ Hemoglobin, g/L; (mean $\pm s d)$} \\
\hline Baseline & $101.5 \pm 25.5$ & 0.405 \\
\hline At the end of treatment & $97.9 \pm 18$ & \\
\hline \multicolumn{3}{|l|}{ Platelet count $x$ 伯 $($ mean $\pm s d)$} \\
\hline Baseline & $213 \pm 915$ & 0.262 \\
\hline At the end of treatment & $194 \pm 64$ & \\
\hline \multicolumn{3}{|c|}{ C-reactive proteine $\mathrm{mg} / \mathrm{L}$; (mean $\pm \mathrm{sd}$ ) } \\
\hline Baseline & $40.3 \pm 80.9$ & 0.783 \\
\hline At the end of treatment & $51 \pm 99.1$ & \\
\hline \multicolumn{3}{|l|}{ D-dimer $\mathrm{ng} / \mathrm{ml}$; (mean $\pm \mathrm{sd}$ ) } \\
\hline Baseline & $1.3 \pm 0.42$ & 0.49 \\
\hline At the end of treatment & $1.08 \pm 0.94$ & \\
\hline \multicolumn{3}{|c|}{ Lactate dehydrogenase U/L: $($ mean $\pm s$} \\
\hline Baseline & $486 \pm 107.6$ & $0.022^{*}$ \\
\hline At the end of treatment & $432 \pm 92.4$ & \\
\hline \multicolumn{3}{|l|}{$\mathrm{ALT}, \mathrm{U} / \mathrm{L}($ mean $\pm \mathrm{sd})$} \\
\hline Baseline & $21.4 \pm 12.5$ & 0.285 \\
\hline At the end of treatment & $17 \pm 8.67$ & \\
\hline \multicolumn{3}{|l|}{ GGT, U/l (mean $\pm \mathrm{sd})$} \\
\hline Baseline & $52.8 \pm 63.7$ & 0.5 \\
\hline At the end of treatment & $52.5 \pm 45.9$ & \\
\hline \multicolumn{3}{|l|}{ Urea $\mathrm{mmol} / \mathrm{L}$ (meats sd) } \\
\hline Baseline & $32.3 \pm 7.2$ & 0.632 \\
\hline At the end of treatment & $31.3 \pm 11.6$ & \\
\hline \multicolumn{3}{|l|}{ Creatinine $\mu \mathrm{ol} / \mathrm{L}$ (mean $\pm \mathrm{sd})$} \\
\hline Baseline & $925 \pm 289.9$ & 0.223 \\
\hline At the end of treatment & $861.6 \pm 367.9$ & \\
\hline
\end{tabular}

In Figure 1, showing the MEWS for 12 days of treatment, there is a significant increase in the MEWS for the period shown $(b=0.017 ; p=0.030)$. 


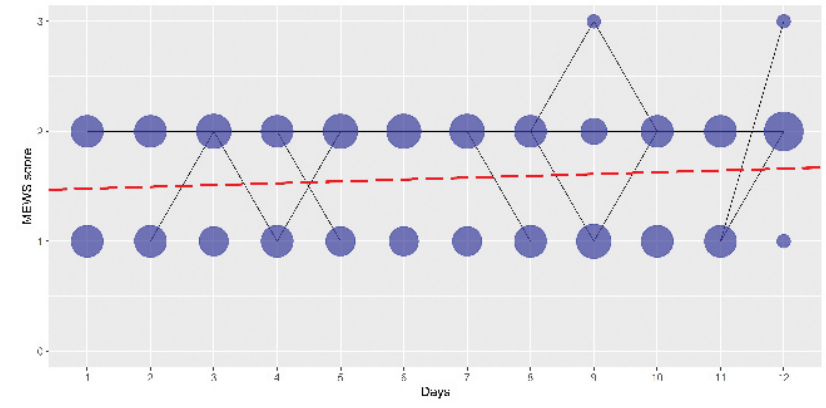

Figure 1. MEWS score, as a predictor of the severity of treatment outcomes of dialysis patients with SARS-Cov-2 infection

In the observed period, there was a significant increase in the degree of MEWS $(b=0.017 ; p=0.030)$.

There was a positive correlation between increase of MEWS and age ( $\mathrm{b}=0.027 ; \mathrm{p}=0.002)$ and arterial hypertension as a concomitant comorbidity $(b=0.700 ; p=$ 0.033).

No correlation was found between the increase in MEWS and sex $(b=0.114 ; p=0.698)$, diabetes mellitus, as comorbidity, $(b=0.219 ; p=0.442)$; duration of hemodialysis treatment $(\mathrm{b}=-0.001 ; \mathrm{p}=0.817)$ and residual diuresis $(\mathrm{b}=$ $0.384 ; p=0.171)$.

The concentration of lactate dehydrogenase at the beginning of treatment was $486 \pm 107.62 \mathrm{U} / \mathrm{L}$, at the end of the two-week treatment was $423.7 \pm 92.4 \mathrm{U} / \mathrm{L}$ and the difference was statistically significant, $p=0.022$. Baseline values of monocytes were $0.46 \pm 0.15 \times 103$, while at the end of treatment the values of monocytes were $0.67 \pm 0.34 \times 103$. The difference between monocytes at the beginning and at the end of treatment was statistically significant $p=0.008$. Other findings of the examined laboratory results did not show statistical significance, Table 2.

\section{DISCUSSION}

The incidence of COVID-19 infection among patients in dialysis centers in the city of Wuhan was up to $10 \%$ among patients and $6.4 \%$ among medical staff [6]. Working with COVID-19 infected patients in a state of declared pandemic was a new experience for all of us that required the urgency of procedures organized by the health service, primarily in the implementation of epidemiological protection measures and treatment of disease that is highly infectious and significantly unknown, both in terms of the protection of patients and medical staff, and in terms of adequate treatment of COVID-19 infected patients. All organizational units in the University Clinical Center Kragujevac subordinated their work to preventing the entry of infection into medical institutions, which meant maximum application of rigorous epidemiological protection measures (control of all those entering the hospital, measuring body temperature, wearing protective masks and gloves, strict application of disinfection measures room). All suspicious febrile conditions and people with symptoms of upper respiratory tract infection are isolated. COVID-19 infection was finally established based on PCR test. This contributed to the fact that Center for Nephrology and Dialysis, University Clinical Center Kragujevac, Serbia, in the first wave of infection, did not have any infected among hemodialysis patients, nor among employed medical and non-medical workers.
Although hemodialysis patients are very susceptible to COVID-19, the infection is probably less serious or fatal for them. Prevention and protection measures should certainly be taken to avoid infection, but it should be emphasized that the organization and implementation of continuous dialysis depuration is a key issue for their survival during the COVID 19 epidemic $[7,8]$. The average age of our subjects of $62.5 \pm$ 13 years does not indicate that it is a geriatric population, and arterial hypertension and diabetes mellitus were the most associated diseases.

Lymphopenia is common in patients with COVID-19 infection and may be a critical mortality risk factor. Among other disorders in laboratory parameters in pneumonia of COVID-19 positive patients, prolonged prothrombin time and elevated lactate dehydrogenase (LDH) have been described. An intriguing phenomenon by Tang et al. [8] observed in his research that the SARS-CoV-2 virus appears to be less harmful to hemodialysis patients. In the general population of patients with COVID-19 infection, the level of inflammatory cytokines in vivo increases significantly and the so-called cytokine storm can be a key cause of worsening condition and even death of patients. Compared with the general population, $T$ cells, Th cells, $T$ cell killers as well natural killer cells are significantly reduced in hemodialysis patients, so it seems that the weakened immune system is not able to establish an effective cellular immune response after the invasion of SARS-CoV-2, which results, no cytokine storm and no serious organ damage in patients on chronic hemodialysis. However, the results of laboratory parameters of our patients did not show changes in number of lymphocytes that would be comparable to the results of these authors. Monocytes are characterized by the ability to recognize "danger signals" through receptors to identify the cause, in response to bacterial, fungal, protozoal and viral pathogens. When they reach the tissues, monocytes are able to differentiate into macrophages and dendritic cells. This property of theirs is based on the cytokine profile and immunophenotyping [9]. Our findings are in accordance with the literature data, namely, at the end of the study, an increased absolute number of monocytes was determined, compared to the initial values, which most likely indicates the body's response to viral infection.

Lactate dehydrogenase initiates cell membrane necrosis, suggesting viral infection or lung damage, such as SARS-CoV-2-induced pneumonia. There is convincing evidence linking LDH levels to the development of COVID-19 disease and there is growing confidence in the use of LDH as a biomarker of the severity of COVID-19 infection [10]. In our study, we confirmed that LDH is a statistically significant parameter of laboratory research in the correlation of COVID-19 infected patients at the beginning and end of treatment.

A large number of COVID-19 infected patients develop pneumonia, which is manifested on radiology by pulmonary consolidation or infiltrates [11]. Three of our patients had an initial clinical picture, with subfebrile fever, with radiological verification of pneumonia. After the applied therapy, there is a complete regression in the radiological finding and clinical picture.

In the first wave of the epidemic it was not recommended no specific effective antiviral drug for COVID19 but attention is increasingly focused on chloroquine such as hydroxychloroquine. Chloroquine phosphate has been shown to have some efficacy against COVID-19-associated pneumonia $[12,13]$. All our patients were treated Cloroquin 
a $250 \mathrm{mg}$ 1x1, macrolide antibiotic and low molecular weight heparin $0.3 \mathrm{ml}$ were introduced except for one patient diagnosed with gynecological malignancy which has not been treated with low molecular weight heparin. We did not exclude antihypertensives from the group of ACE inhibitors, despite certain dilemmas regarding the use of ACE inhibitors, despite the fact that previous studies [14] suggested that the ability to bind angiotensin-converting enzyme 2 (ACE2) is strongly associated with coronavirus infectivity and the severity of the clinical picture. Other therapies were included according to the treatment protocol of patients on chronic hemodialysis, as well as the accompanying comorbidities. All patients were substituted with erythropoiesis stimulators. One patient had symptoms of anginal pain and a prolonged $\mathrm{p}-\mathrm{Q}$ interval during treatment, which we understood as a reaction to Chloroquin but this occurred at the end of the two-week treatment. No patient required ventilatory support. Unfortunately, on the thirteenth day of treatment, there was a lethal outcome in one patient with significant comorbidities. This patient was also COVID-19 positive on PCR retest on the second test. The other patients with a negative PCR test, improved health, were returned to the parent dialysis center for further treatment with chronic hemodialysis.

Patients with end-stage renal disease, especially those treated with chronic dialysis, are at constant risk for lethal exit outcome. A mechanism to identify those patients who are least likely to survive after 12 months would provide useful prognostic information in the context of a joint decision on how to proceed [15]. The results of our study showed a significant increase in MEWS and positive correlation between increase of MEWS and age and arterial hypertension as a concomitant comorbidity is elderly patients with arterial hypertension have a greater chance of elevated MEWS scores and serious complications to their health. On the other hand, there was no correlation between the increase in MEWS and diabetes mellitus, as comorbidity, duration of hemodialysis treatment and residual diuresis. To our knowledge, this is the first study to correlate the MEWS with in COVID-19 infected hemodialysis patients. The patient in our study with the highest MEWS, has lethally outcome. Different approaches to these problems may yield different results in the development and validation of MEWS. Obviously, there is great potential that the MEWS can be helpful in making the right clinical decisions. There are some other models in external validation studies that can lead to the application of inferior scoring systems, with false beliefs about their ability to predict and generalize.

\section{CONCLUSION}

Our research showed that MEWS is an important parameter for assessing the clinical condition and outcome of treatment of dialysis patients who had SARS-Cov-2 infection, especially important is the positive correlation of MEWS with age and arterial hypertension, as an accompanying comorbidity.

\section{REFERENCES}

1. Naicker S, Yang CW, Hwang SJ, Liu BC, Chen JH, Jha V. The Novel Coronavirus 2019 epidemic and kidneys. Kidney International 2020; 97(5): 824-828.

2. Wang R, Liao C, He H, Hu C, Wei Z, Hong Z, Zhang C, Liao M, Shui H. COVID-19 in Hemodialysis Patients: A Report of 5 Case. AJKD 2020; 76 (1): 141-143. doi: http://10.1053/j.ajkd.2020.03.009.

3. Kliger AS, Mitigating SJ. Risk of COVID-19 in Dialysis Facilities CJASN 2020; 15(5):707-709. doi: https://doi.org/10.2215/CJN.03340320.

4. Brekke IJ, Puntervoll LH, Pedersen PB, Kellett J, Brabrand M. The value of vital sign trends in predicting and monitoring clinical deterioration: A systematic review. PLOS ONE 2019;14(1). e0210875. https://doi.org/10.1371/journal.pone.0210875.

5. Subbe CP, Kruger M, Rutherford P, Gemmel L. Validation of a modified Early Warning Score in medical admissions. QJM 2001; 94(10): 521-526. https://doi.org/10.1093/qjmed/94.10.521.

6. Li J, Xu G. Lessons from the Experience in Wuhan to Reduce Risk of COVID-19 Infection in Patients Undergoing Long-Term Hemodialysis. CJASN 2020; 15 (5): 717-719. doi: https://doi.org/10.2215/CJN.03420320.

7. Ikizler TA, Kliger AS. Minimizing the risk of COVID-19 among patients on dialysis. Nature Reviews Nephrology 2020; 16: 311-313.

8. Tang B, Li S, Xiong Y, Tian M, Yu J, Xu L, Zhang L, Li Z, Ma J, Wen F, Feng Z, Liang X, Shi W, Liu S. Coronavirus Disease 2019 (COVID-19) Pneumonia in a Hemodialysis Patient. Kidney Med 2020; 2(3): 354-358. doi: 10.1016/j.xkme.2020.03.001.

9. Chiu S, Bharat A. Role of monocytes and macrophages in regulating immune response following lung transplantation. Curr Opin Organ Transplant 2016; 21(3): 239-245. doi: 10.1097/MOT.0000000000000313.

10. Kermali M, Khalsa RK, Pillai K, Ismail Z, Harky A. The role of biomarkers in diagnosis of COVID-19 - A systematic review. Life Sci 2020; 254: 117788. doi: 10.1016/j.lfs.2020.117788

11. Goicoechea M, Ca'mara LAS, Maci' as N, de Morales AM, Rojas AG, Bascun ana A, Arroyo D, Vega A, Abad S, Verde E, PrietoAMG, Verdalles U, Barbieri D, Delgado AF, Carbayo J, Mijaylova A, Acosta A, Melero R, Tejedor A, Benitez PR, de Jose AP, Fererro MLR, Anaya F, Rengel M, Barraca D, Luno J, Aragoncillo I. COVID-19: clinical course and outcomes of 36 hemodialysis patients in Spain. Kidney International 2020;98(1): 27-34. https://doi.org/10.1016/j.kint.2020.04.031.

12. Ronco C, Reis T. Kidney involvement in COVID-19 and rationale for extracorporeal therapies. Nat Rev Nephrol 2020; 16 : 308-310. https://doi.org/10.1038/s41581-020-0284-7. 
13. Ferrey AJ, Choi G, Hanna RM, Chang Y, Tantisattamo E, Ivaturi K, Park E, Nguyen L, Wang B, Tonthat S, Rhee CM, Reddy U, Lau WL, Huang SS, Gohil S, Amin AN, Hsieh L, Cheng TT, Lee RA, Kalantar-Zadeh K. A Case of Novel Coronavirus Disease 19 in a Chronic Hemodialysis Patient Presenting with Gastroenteritis and Developing Severe Pulmonary Disease. Am J Nephrol 2020; 51(5): 337-342. doi: 10.1159/000507417.

14. Mali SN, Thorat BR, Chopade AR. A Viewpoint on Angiotensin-Converting Enzyme 2, Anti-Hypertensives and Coronavirus Disease 2019 (COVID-19). Infect Disord Drug Targets 2020. doi: 10.2174/1871526520666200511005546.

15. Schmidt RJ, Landry DL, Cohen L, Moss AH, Dalton C, Nathanson BH, Germain MJ. Derivation and validation of a prognostic model to predict mortality in patients with advanced chronic kidney disease. NDT 2018; 34(9): 1517-1525. doi: 10.1093/ndt/gfy305. 